\title{
Mitochondrial DNA variability in populations of Centris aenea (Hymenoptera, Apidae), a crop-pollinating bee in Brazil
}

\author{
V.S. Ferreira ${ }^{1,2}$, C.M.L. Aguiar ${ }^{3}$, E.J.F. Oliveira ${ }^{3}$, M.A. Costa ${ }^{4}$, \\ G.M.M. Santos ${ }^{3}$ and J.G. Silva ${ }^{2,4}$ \\ ${ }^{1}$ Laboratório de Entomologia, \\ Universidade Federal do Vale do São Francisco, Campus Ciências Agrárias, \\ Petrolina, PE, Brasil \\ ${ }^{2}$ Programa de Pós-Graduação em Zoologia, \\ Universidade Estadual de Santa Cruz, Ilhéus, BA, Brasil \\ ${ }^{3}$ Laboratório de Entomologia, Departamento de Ciências Biológicas, \\ Universidade Estadual de Feira de Santana, Feira de Santana, BA, Brasil \\ ${ }^{4}$ Departamento de Ciências Biológicas, \\ Universidade Estadual de Santa Cruz, Ilhéus, BA, Brasil \\ Corresponding author: V.S. Ferreira \\ E-mail: vininasf@gmail.com
}

Genet. Mol. Res. 12 (1): 830-837 (2013)

Received May 31, 2012

Accepted December 20, 2012

Published March 15, 2013

DOI http://dx.doi.org/10.4238/2013.March.15.3

\begin{abstract}
Centris spp are oil-collecting solitary bees that are valuable pollinators of crops such as Brazil nut, cashew, and acerola. We investigated the genetic variability of populations of $C$. aenea in the northeastern region of Brazil. Total DNA was extracted from 59 individuals from 6 locations in the States of Pernambuco and Bahia and a 600-650-bp fragment of the mitochondrial COI/COII region amplified by PCR, followed by digestion with the restriction enzymes DraI and SspI. PCR-RFLP analysis revealed eight different haplotypes among the populations. Haplotype A1, revealed by DraI, was the most frequent (50\%), and haplotypes A3 and A4 were exclusive to Feira de Santana, Bahia and Morro do Chapéu, Bahia, respectively. Among the
\end{abstract}


haplotypes revealed by $S s p \mathrm{I}, \mathrm{B} 2$ was the most frequent (37\%) and B3 was exclusive to Feira de Santana. This information revealing high haplotype diversity will be useful for developing management strategies for Centris, especially because of increasing interest in the rearing and/ or relocation of these bees for crop pollination.

Key words: Centridini; PCR-RFLP; Population variation; Solitary bee

\section{INTRODUCTION}

Recent studies on bee fauna in orchards have indicated that Centris aenea females are frequent visitors of cultivated plants such as acerola (Malpighia emarginata) and guava (Psidium guajava), contributing to improvement of productivity and fruit quality (Freitas et al., 1999; Berti-Boti, 2001; Guedes et al., 2011; Siqueira et al., 2011; Vilhena et al., 2012). Based on the extensive distribution of crops pollinated by C. aenea in Brazil (for instance, acerola is cultivated from the State of Rio Grande do Sul in the southern region of the country to the State of Ceará in the northeastern region) (Freitas et al., 1999; Carvalho, 2003) and on the possibility of relocating bees between different geographic regions to provide additional pollinators, studies on population variation have become of paramount importance.

Species in the genus Apis are the best studied among the Apoidea, for which there is a large body of literature on genetic variation that have helped studies on other bee groups as a parameter of comparison (Diniz et al., 2003; Francoy et al., 2009; Ting et al., 2009; Ivanova et al., 2010; Ji et al., 2011).

Relatively few genetic studies have investigated bee species within other genera, such as Plebeia remota (Francisco et al., 2001), Eufrisea violacea (Sofia et al., 2005), Macrotera portalis (Danforth et al., 2003), Tetragonisca angustula (Oliveira et al., 2004), Partamona helleri (Brito and Arias, 2010), Partamona seridoensis (Fernandes et al., 2012), Melipona subnitida (Cruz et al., 2006), and Euglossa fimbriata (Suzuki et al., 2010). Some of these studies have used PCR-RFLP (Francisco and Arias, 2010; Brito and Arias, 2010; Suzuki et al., 2010) revealing interesting information that has allowed researchers to distinguish populations. The COI/COII mitochondrial DNA region is known to be highly variable in Apis mellifera (Garnery et al., 1993; Franck et al., 1998) and stingless bees (Francisco et al., 2001; Fernandes-Salomão et al., 2002; Weinlich et al., 2004; Moretto and Arias, 2005; Brito and Arias, 2005).

The only information available on population variation of $C$. aenea is a morphometric study (Ferreira et al., 2011), which revealed low population variation. To address this lack of information about the genetic variation in this species, we investigated the levels of genetic differentiation between populations of $C$. aenea in the northeastern region of Brazil using PCR-RFLP in the COI/COII mitochondrial DNA region.

\section{MATERIAL AND METHODS}

Females $(\mathrm{N}=59)$ of $C$. aenea were collected from six localities in the States of Bahia and Pernambuco, in the northeastern region of Brazil (Tables 1 and 2). Sampled areas included natural vegetation and acerola orchards usually visited by $C$. aenea (Table 1). Specimens were 
Table 1. Number of Centris aenea females, sampled localities, geographical coordinates, and number of individuals used in the PCR-RFLP analysis (modified from Ferreira et al., 2011).

\begin{tabular}{|c|c|c|c|c|c|c|}
\hline Locality & Vegetation & State & Latitude & Longitude & $\mathrm{N}$ & PCR/RFLP \\
\hline Feira de Santana & Caatinga & Bahia & $12^{\circ} 11^{\prime} 58.3^{\prime \prime}$ & $38^{\circ} 58^{\prime} 05.95^{\prime \prime}$ & 10 & 3 \\
\hline Mucugê & Campo rupestre & Bahia & $12^{\circ} 50^{\prime} 45^{\prime \prime}$ & $41^{\circ} 31^{\prime} 04^{\prime \prime}$ & 9 & 2 \\
\hline Morro do Chapéu & Caatinga & Bahia & $11^{\circ} 34^{\prime} 29^{\prime \prime}$ & $41^{\circ} 11^{\prime} 00^{\prime \prime}$ & 10 & 2 \\
\hline Palmeiras & Cerrado & Bahia & $12^{\circ} 32^{\prime} 44^{\prime \prime}$ & $41^{\circ} 43^{\prime} 31^{\prime \prime}$ & 10 & 1 \\
\hline Cruz das Almas & Acerola orchard & Bahia & $12^{\circ} 40^{\prime} 39^{\prime \prime}$ & $39^{\circ} 40^{\prime} 23^{\prime \prime}$ & 10 & 5 \\
\hline Petrolina & Acerola orchard & Pernambuco & $09^{\circ} 09^{\prime}$ & $40^{\circ} 22^{\prime}$ & 10 & 5 \\
\hline
\end{tabular}

collected using an entomological net, fixed with ethyl acetate, and preserved in $100 \%$ ethanol. Voucher specimens were deposited at the Coleção Entomológica Prof. Jonhan Becker of the Museu de Zoologia da Universidade Estadual de Feira de Santana (MZUEFS).

Total nucleic acid extractions from the thorax of alcohol-preserved individuals followed three protocols: 1) phenol-chloroform modified from Raeder and Broda (1985), with the addition of $5 \mu \mathrm{L} 20 \mu \mathrm{g} / \mathrm{mL}$ proteinase $\mathrm{K}$ before incubation and non-simultaneous addition of phenol and chloroform; 2) phenol-chlorophorm by Han and McPheron (1997), and 3) the "DNeasy Blood and Tissue kit" (QIAGEN). A fragment of 600-650 bp within the COI/COII mitochondrial region was amplified by polymerase chain reaction (PCR) using primers 5'-TCTATACCACGACGTTATTC-3' and 5'-GATCAATATCATTGATGACC-3' (Hall and Smith, 1991). PCRs were carried out in $25 \mu \mathrm{L}$ according to Gasparich et al. (1995), using $2 \mu \mathrm{L}$ genomic DNA. The cycle program consisted of an initial denaturation step of $5 \mathrm{~min}$ at $94^{\circ} \mathrm{C}$, followed by 40 cycles of $1 \mathrm{~min}$ at $94^{\circ} \mathrm{C}, 1 \mathrm{~min}$ at $44^{\circ}$ or $45^{\circ} \mathrm{C}, 2 \mathrm{~min}$ at $72^{\circ} \mathrm{C}$, with a final extension step of $10 \mathrm{~min}$ at $70^{\circ} \mathrm{C}$.

PCR products were visualized on ethidium bromide-stained $1 \%$ agarose gels in $1 \mathrm{X}$ TBE buffer, along with a 100-bp ladder (GE Healthcare).

PCR products of 18 individuals were digested with DraI and SspI (Table 1).

The digestion reaction mixture was prepared in a final volume of $20 \mu \mathrm{L}$, using $2 \mu \mathrm{L}$ $10 \mathrm{X}$ buffer, $1 \mathrm{U}$ DraI or $S s p \mathrm{I} ; 10.8 \mu \mathrm{L}$ milliQ water, and $7 \mu \mathrm{L}$ PCR product and incubated at $37^{\circ} \mathrm{C}$ for $12 \mathrm{~h}$. Digestion products were visualized by electrophoresis on $2-3 \%$ ethidium bromide-stained agarose gels using a 100-bp ladder to estimate fragment size.

Median-joining networks (Bandelt et al., 1999) were reconstructed for mitochondrial haplotypes, with the Network version 4.5.0.0 program (www.fluxus-engineering.com).

\section{RESULTS}

Digestion of the amplified fragment of the COI/COII region with DraI revealed four restriction patterns (Figure 1): haplotype A1, uncut fragment (600 bp), haplotype A2 (390 and $180 \mathrm{bp}$ fragments), haplotype A3 (350 and $140 \mathrm{bp}$ fragments) and haplotype A4 (400 and 230 bp fragments).

Digestion with $S s p$ I also generated four restriction patterns (Figure 1): haplotype B4, uncut fragment (600 bp), haplotype B1 (300 and 190 bp fragments), haplotype B2 (265 and $190 \mathrm{bp}$ fragments), haplotype B3 (265 and $210 \mathrm{bp}$ fragments).

Among the haplotypes revealed by digestion with $S s p$ I, haplotype B1 was found in samples from Cruz das Almas and Petrolina, which are $399 \mathrm{~km}$ apart (Table 2). Haplotype 
B2 was the most frequent (37\%) and detected in Feira de Santana and in two localities in the Chapada Diamantina (Mucugê and Morro do Chapéu), whereas haplotype B4 was found in Feira de Santana and Petrolina, which are 394 km apart. Haplotype B3 was exclusive of Feira de Santana (Table 2).

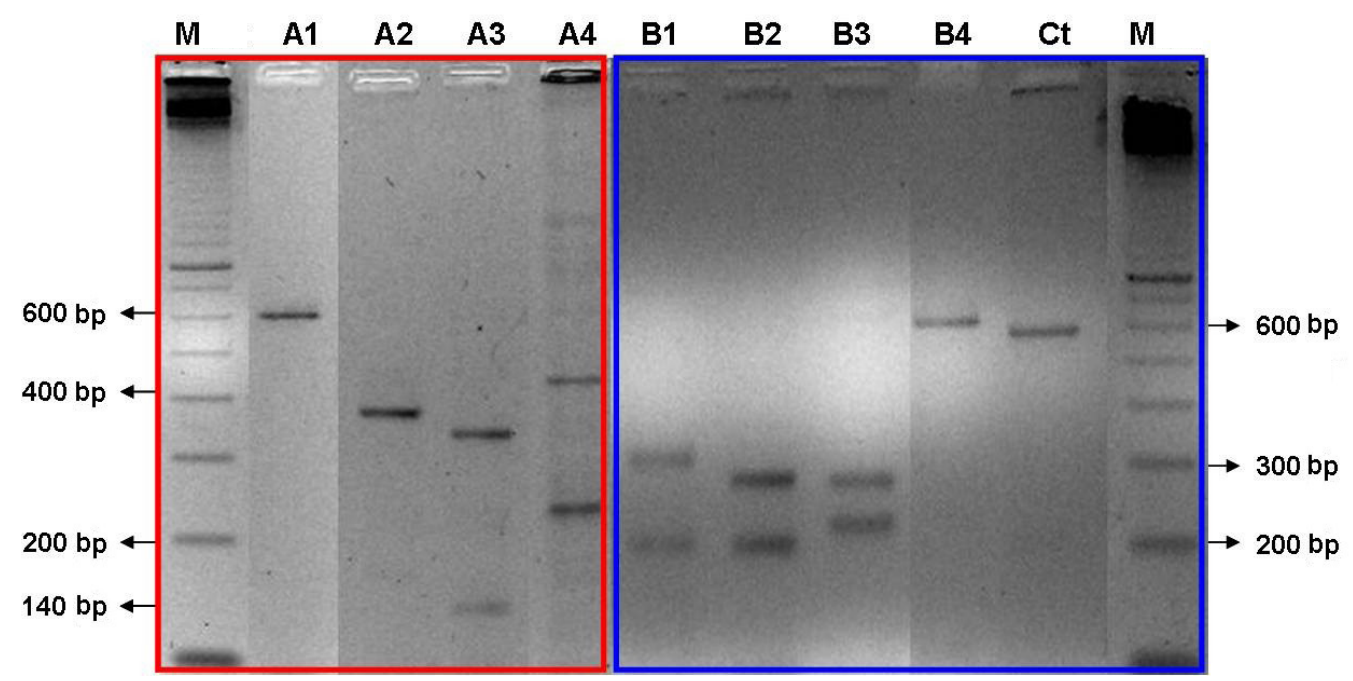

Figure 1. Two percent agarose gel (red) and 3\% (blue) stained with $25 \mu \mathrm{g} / \mu \mathrm{L}$ ethidium bromide showing 8 lanes with the haplotypes identified in 6 populations of Centris aenea. Lane $M=100$-bp ladder (GE Healthcare); lanes $A 1, A 2, A 3$, and $A 4=D r a I$ haplotypes; lanes $B 1, B 2, B 3$, and $B 4=S s p I$ haplotypes; lane $C t=$ control with nondigested PCR product.

Table 2. Distance in km among localities sampled based on latitude and longitude.

\begin{tabular}{|c|c|c|c|c|c|}
\hline & FSA & $\mathrm{MU}$ & $\mathrm{MC}$ & $\mathrm{PE}$ & PAL \\
\hline $\mathrm{MU}$ & 277.8 & & & & \\
\hline $\mathrm{MC}$ & 256.4 & 145.9 & & & \\
\hline PE & 394.2 & 429.7 & 284 & & \\
\hline PAL & 296.9 & 175.1 & 123 & 405.7 & \\
\hline $\mathrm{CA}$ & 78.82 & 200.9 & 204.9 & 399.5 & 223.2 \\
\hline
\end{tabular}

FSA $=$ Feira de Santana; $\mathrm{MU}=$ Mucugê $; \mathrm{MC}=$ Morro do Chapéu; $\mathrm{PE}=$ Petrolina; $\mathrm{PAL}=$ Palmeiras; $\mathrm{CA}=$ Cruz das Almas (modified from Ferreira et al., 2011).

Among the haplotypes revealed by digestion with DraI, haplotype A1 was the most frequent $(50 \%)$ and was detected in 5 of the 6 populations; it was absent only in the three samples from Feira de Santana. Haplotype A2 was detected in three populations (Feira de Santana, Mucugê, and Petrolina) in 30\% of all samples analyzed. Haplotypes A3 and A4 were each exclusive of one population, Feira de Santana and Morro do Chapéu, respectively. In the three localities sampled in the Chapada Diamantina (Palmeiras, Morro do Chapéu, and Mucugê), three distinct haplotypes were detected (A1, A2, and A4) (Table 3).

The population of Feira de Santana had the highest haplotype diversity (five) in only three individuals studied and also the largest number of exclusive haplotypes (A3 and B3) (Table 3). 
Table 3. DraI and SspI haplotypes identified 6 populations of Centris aenea.

\begin{tabular}{lcccccc}
\hline Haplotypes & \multicolumn{5}{c}{ Locality } \\
\cline { 2 - 7 } & CA (5) & FSA (3) & MC (2) & Mu (2) & Pe (5) & Pal (1) \\
\hline A1 & $*$ & $*$ & $*$ & $*$ & $*$ & $*$ \\
A2 & & $*$ & $*$ & & $*$ \\
A3 & $*$ & $*$ & $*$ & \\
A4 & & $*$ & $*$ & $*$ & \\
B1 & & $*$ & & & $*$ \\
B2 & & & & $*$ \\
B3 & & & & \\
B4 & & $*$ & & & \\
\hline
\end{tabular}

$\mathrm{CA}=$ Cruz das Almas; FSA = Feira de Santana; $\mathrm{MC}=$ Morro do Chapéu; $\mathrm{Mu}=$ Mucugê; Pe $=$ Petrolina; Pal = Palmeiras. Numbers in parentheses represent the number of individuals per locality.

The haplotype network (Figure 2) shows evidence of genetic polymorphism in populations of $C$. aenea and some genetic structuring in the populations from Cruz das Almas, Petrolina, Feira de Santana, and Mucugê, which formed distinct haplogroups (Figure 2).

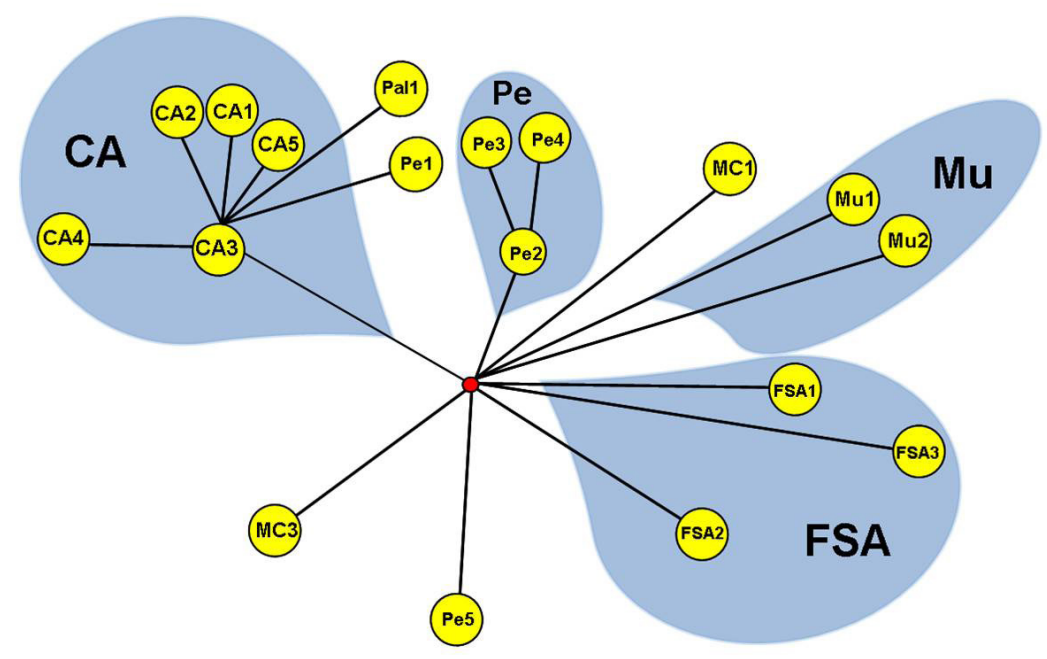

Figure 2. Median-joining network diagram for $D r a \mathrm{I}$ and $S s p \mathrm{I}$ haplotypes. The branch length corresponds to the genetic distance between haplotypes. $\mathrm{CA}=$ Cruz das Almas; $\mathrm{Pal}=$ Palmeiras; $\mathrm{Pe}=$ Petrolina; $\mathrm{MC}=\mathrm{Morro}$ do Chapéu; $\mathrm{Mu}=$ Mucugê; FSA = Feira de Santana.

\section{DISCUSSION}

The size of the amplified COI/COII fragment of C. aenea (600-650 bp) was similar to what has been found for Melipona species (approximately 630-650 bp) (Fernandes-Salomão et al., 2002) and shorter than the same region in Partamona species (929 bp) (Brito and Arias, 2005). In A. mellifera subspecies, the COI/COII region was considerably longer and had variable length due to up to $450 \mathrm{bp}$ in the intergenic region (noncoding region between the RNAtLeu and COII genes), which normally ranges from 200 to $650 \mathrm{bp}$ (Cornuet and Garnery, 1991). Sequencing of the mitochondrial genome of Melipona bicolor (Silvestre et 
al., 2008) confirmed that the intergenic region is not present in Melipona, Plebeia (Francisco et al., 2001), or Partamona (Brito and Arias, 2005). We amplified the COI/COII region in $C$. aenea with the same primers used for A. mellifera and Melipona species, which suggests that C. aenea also lacks the intergenic region, as do the meliponine bees (Francisco et al., 2001; Brito and Arias, 2005). However, it is still necessary to sequence this fragment in C. aenea and compare it with the available sequences of other bee species, since presence or absence of an intergenic region in the $\mathrm{COI} / \mathrm{COII}$ fragment can explain a substantial part of the genetic variation observed in different bee genera. In contrast with a morphometric study that showed low population variation in C. aenea (Ferreira et al., 2011), we found intra- and interpopulational variation in $C$. aenea based on the 8 haplotypes identified thus far.

The haplotype diversity observed ( 8 haplotypes, with 2 restriction enzymes in 6 populations) in the C. aenea populations that we sampled was higher than that found for the social bee Partamona helleri (10 haplotypes, with 6 restriction enzymes, in 11 populations) (Brito and Arias, 2010).

Interpopulational divergence in $C$. aenea shown in the median-joining network was found between both geographically close (Feira de Santana and Cruz das Almas, $78.82 \mathrm{~km}$ ) and more distant populations (Cruz das Almas and Petrolina, $399.5 \mathrm{~km}$ apart). Four haplogroups were defined: Cruz das Almas, Petrolina, Feira de Santana, and Mucugê, without direct relationship with their relative geographic locations (Table 2; Figure 2). Feira de Santana and Cruz das Almas were the closest sampled locations $(78.82 \mathrm{~km}$ ) (Table 2); yet their haplogroups occupied opposite positions (Figure 2). Moreover, branch length indicated a relatively great genetic distance between the haplotypes from these two locations. Our results suggest population structure due to four distinct haplogroups.

The observed distribution of haplotypes among the $C$. aenea populations that we studied might be related to the fragmentation and/or reduction of its original distribution range and the influence of environmental barriers inadequate for colonization by this bee. C. aenea has some environmental requirements for the maintenance of its populations, including a need for oil-producing plants, which can impose barriers to gene flow. This seems to be a plausible explanation, since, with rare exceptions, Centris species are known to depend on floral oilproducing plants such as species in the families Malpighiaceae and Krameriaceae, for building their nests and/or feeding their larvae (Gaglianone, 2003; Aguiar and Garófalo, 2004; Aguiar et al., 2006). Ramalho and Silva (2002) found that in a restinga environment in the Brazilian Northeast, the population abundance of Centridini was proportional to the abundance of oilproducing plants. These plants, in turn, are abundant in areas with natural vegetation but are not common in anthropized areas.

The management of bees, including $C$. aenea, can be an alternative to the crisis in ecosystem services of crop pollination caused by burning, introduction of competing species, habitat fragmentation, and pesticides (Nabhan and Buchmann, 1997). It could also be an interesting alternative for Brazilian agriculture, which is highly dependent on crop pollination services on a large scale provided by a single bee species (A. mellifera). The rearing, relocation, and release of solitary bees, such as $C$. aenea, into orchards can be feasible in Brazil, as it is already an established practice in other countries, using other species of solitary bees (Bosch et al., 2002).

Further studies regarding genetic variation within $C$. aenea should be carried out with other molecular markers and a broader sampling. Such studies coupled with investigation on 
flight range and reproductive biology of this species (such as preferred mating sites and dispersion ability of males and virgin females) can help us to better understand variation in $C$. aenea populations.

\section{ACKNOWLEDGMENTS}

We thank Kátia M. Lima, Lídia N. Silva, and Vanderly Andrade-Souza for their help in the laboratory. Research supported by Conselho Nacional de Desenvolvimento Científico e Tecnológico (CNPq; Process \#474408/2004-3), Universidade Estadual de Santa Cruz (UESC), and Universidade Estadual de Feira de Santana (UEFS). V.S. Ferreira was supported by a fellowship from Conselho Nacional de Desenvolvimento Científico e Tecnológico (CNPq) during her MSc. (Process \#136093/2008 6). G.M.M. Santos and C.M.L. Aguiar received productivity fellowship from CNPq (Proc. \#309711/2009-6 and \#06403/2012-9).

\section{REFERENCES}

Aguiar CML and Garófalo CA (2004). Nesting biology of Centris (Hemisiella) tarsata Smith (Hymenoptera, Apidae, Centridini). Rev. Bras. Zool. 21: 477-486.

Aguiar CML, Garófalo CA and Almeida GF (2006). Biologia de nidificação de Centris (Hemisiella) trigonoides Lepeletier (Hymenoptera, Apidae, Centridini). Rev. Bras. Zool. 23: 323-330.

Bandelt HJ, Forster P and Röhl A (1999). Median-joining networks for inferring intraspecific phylogenies. Mol. Biol. Evol. 16: 37-48.

Berti-Boti J (2001). Polinização Entomófila da Goiabeira (Psidium guajava L., Myrtaceae): Influência de Fragmentos Florestais Próximos aos Pomares na Região de Santa Teresa, Espírito Santo. Master's thesis, UFV, Viçosa.

Bosch J, Bosch J and Kemp WP (2002). Developing and establishing bee species as crop pollinators: the example of Osmia spp. (Hymenoptera: Megachilidae) and fruit trees. Bull. Entomol. Res. 92: 3-16.

Brito RM and Arias MC (2005). Mitochondrial DNA characterization of two Partamona species (Hymenoptera, Apidae, Meliponini) by PCR+RFLP and sequencing. Apidologie 36: 431-437.

Brito RM and Arias MC (2010). Genetic structure of Partamona helleri (Apidae, Meliponini) from Neotropical Atlantic rainforest. Insectes Soc. 57: 413-419.

Carvalho RIN (2003). Frutificação efetiva da aceroleira em condições outonais no município de Viamão-RS, Brasil. Rev. Acad. Ciênc. Agrár. Ambient. 1: 23-26.

Cornuet JML and Garnery L (1991). Mitochondrial DNA variation in honeybees and its phylogeographic implications. Apidologie 22: 627-642.

Cruz DO, Jorge DMM, Pereira JOP, Torres DC, et al. (2006). Intraspecific variation in the first internal transcribed spacer (ITS1) of the nuclear ribosomal DNA in Melipona subnitida (Hymenoptera, Apidae), an endemic stingless bee from northeastern Brazil. Apidologie 37: 376-386.

Danforth BN, Shuqing JI and Ballard LJ (2003). Gene flow and population structure in an oligolectic desert bee, Macrotera (Macroteropsis) portalis (Hymenoptera: Andrenidae). J. Kans. Entomol. Soc. 76: 221-235.

Diniz NM, Soares AEE, Sheppard WS and Del Lama MA (2003). Genetics structure of honeybee populations from southern Brazil and Uruguay. Genet. Mol. Biol. 26: 47-52.

Fernandes CRM, Martins CF, Ferreira KM and Del Lama MA (2012). Gene variation, population differentiation, and sociogenetic structure of nests of Partamona seridoensis (Hymenoptera: Apidae, Meliponini). Biochem. Genet. 50: 325-335.

Fernandes-Salomão TM, Muro-Abad JI, Campos LAO and Araújo EF (2002). Mitochondrial and nuclear DNA characterization in the Melipona species (Hymenoptera, Meliponini) by RFLP analisys. Hereditas 137: 229-233.

Ferreira VS, Aguiar CML, Costa MA and Silva JG (2011). Morphometric analysis of populations of Centris aenea Lepeletier (Hymenoptera: Apidae) from Northeastern Brazil. Neotrop. Entomol. 40: 97-102.

Francisco FO and Arias MC (2010). Inferences of evolutionary and ecological events that influenced the population structure of Plebeia remota, a stingless bee from Brazil. Apidologie 41: 216-224.

Francisco FO, Silvestre D and Arias MC (2001). Mitochondrial DNA characterization of five species of Plebeia (Apidae: Meliponini): RFLP and restriction maps. Apidologie 32: 323-332. 
Franck P, Garnery L, Loiseau A, Oldroyd BP, et al. (1998). The original of west European subspecies of honeybees (Apis mellifera): new insights from microsatellite and mitochondrial data. Evolution 52: 1119-1134.

Francoy TM, Wittmann D, Steinhage V, Drauschke M, et al. (2009). Morphometric and genetic changes in a population of Apis mellifera after 34 years of Africanization. Genet. Mol. Res. 8: 709-717.

Freitas BM, Alves JE, Brandão GF and Araujo ZB (1999). Pollination requirementes of West Indian cherry (Malpighia emarginata) and its putative pollinators, Centris bees, in NE Brazil. J. Agr. Sci. 133: 303-311.

Gaglianone MC (2003). Abelhas da Tribo Centridini na Estação Ecológica de Jataí: Composição de Espécies e Interações com Flores de Malpighiaceae. In: Apoidea Neotropica (Melo GAR and Alves-dos-Santos I, eds.). Editora da Universidade do Extremo Sul Catarinense, Criciúma, 279-284.

Garnery L, Solignac M, Celebrano G and Cornuet JM (1993). A simple test using restricted PCR-amplified mitochondrial DNA to study the genetic structure of Apis mellifera L. Experientia 49: 1016-1021.

Gasparich GE, Sheppard WS, Han HY, McPheron BA, et al. (1995). Analysis of mitochondrial DNA and development of PCR-based diagnostic molecular markers for Mediterranean fruit fly (Ceratitis capitata) populations. Insect Mol. Biol. 4: 61-67.

Guedes RS, Zanella FCV, Martins CF and Schlindwein C (2011). Déficit de polinização da aceroleira no período seco do semiárido paraibano. Rev. Bras. Frutic. 33: 465-471.

Hall HG and Smith DR (1991). Distinguishing African and European honeybee matrilines using amplified mitochondrial DNA. Proc. Natl. Acad. Sci. 88: 4548-4552.

Han HY and McPheron BA (1997). Molecular phylogenetic study of Tephritidae (Insecta: Diptera) using partial sequences of the mitochondrial 16S ribosomal DNA. Mol. Phylogenet. Evol. 7: 17-32.

Ivanova EN, Petrov P, Bouga M, Emmanouel NG, et al. (2010). Genetic variation in honey bee (Apis mellifera L.) populations from Bulgaria. J. Apic. Sci. 54: 51-62.

Ji T, Ling Y and Chen G (2011). Genetic diversity and population structure of Chinese honeybees (Apis cerana) under microsatellite markers. Afr. J. Biotechnol. 10: 1712-1720.

Moretto G and Arias MC (2005). Detection of mitochondrial DNA restriction site differences between the subspecies of Melipona quadrifasciata Lepeletier (Hymenoptera: Apidae: Meliponini). Neotrop. Entomol. 34: 381-385.

Nabhan GP and Buchman SL (1997). Services Provided by Pollinators. In: Natures's Services (Dally GC, ed.). Island Press, Washington, 133-150.

Oliveira RC, Nunes FMF, Campos APS, Vasconcelos SM, et al. (2004). Genetic divergence in Tetragonisca angustula Latreille, 1811 (Hymenoptera, Meliponinae, Trigonini) based on rap markers. Genet. Mol. Biol. 27: 181-186.

Raeder U and Broda P (1985). Rapid preparation of DNA from filamentous fungi. Lett. Appl. Microbiol. 1: 17-20.

Ramalho M and Silva M (2002). Flora oleífera e sua guilda de abelhas em uma comunidade de restinga tropical. Sitientibus 2: 34-43.

Silvestre D, Dowton M and Arias MC (2008). The mitochondrial genome of the stingless bee Melipona bicolor (Hymenoptera, Apidae, Meliponini): Sequence, gene organization and a unique tRNA translocation event conserved across the tribe Meliponini. Genet. Mol. Biol. 31: 451-460.

Siqueira KMM, Martins CF, Kill LHP and Silva LT (2011). Estudo comparativo da polinização em variedades de aceroleiras (Malpighia emarginata dc. Malpighiaceae). Rev. Caatinga 24: 18-25.

Sofia SH, Paula FM, Santos AM, Almeida FS, et al. (2005). Genetic struture analysis of Eufriesea violacea (Hymenoptera, Apidae) populations from southern Brazilian Atlantic rainforest remnants. Genet. Mol. Biol. 28: 479-484.

Suzuki KM, Arias MC, Giangarelli DC, Freiria GA, et al. (2010). Mitochondrial DNA diversity of orchid bee Euglossa fimbriata (Hymenoptera: Apidae) populations assessed by PCR-RFLP. Biochem. Genet. 48: 326-341.

Ting J, Ling Y, Min L, Wen-Bin B, et al. (2009). Analysis of genetic diversity of the higher and lower royal jelly producing bee in China with microssatellite markers. Res. J. Biol. Sci. 4: 231-235.

Vilhena AMGF, Rabelo LS, Bastos EMAF and Augusto SC (2012). Acerola pollinators in the savanna of Central Brazil: temporal variations in oil-collecting bee richness and a mutualistic network. Apidologie 43: 51-62.

Weinlich R, Francisco FO and Arias MC (2004). Mitochondrial DNA restriction and genomic maps of seven species of Melipona (Apidae: Meliponini). Apidologie 35: 365-370. 